\title{
SEJARAH DAN PENCERAHAN MASYARAKAT: Paradigma Pengajaran Sejarah di Persimpangan Jalan
}

\author{
Singgih Tri Sulistiyono *)
}

\begin{abstract}
Abstrak
Penelititan dan penulisan sejarah telah menunjukkan perkembangan yang luar biasa dalam era reformasi ini. Berbagai kontroversi dalam penulisan sejarah menyebabkan dunia pengajaran sejarah di sekolah menghadapi dilema. Penulisan sejarah dan kesadaran sejarah memiliki kaitan yang sangat erat. Guru sejarah mampu memberikan pencerahan sosial kepada muridmuridnya melalui pengajaran sejarah. Pengajaran sejarah dengan paradigma yang sesuia dengan hakekat sejarah akan membebaskan masyarakat dari belenggu mitos masa lampau. Penulisan sejarah akan menjadi salah satu sarana untuk menciptakan kesadaran sejarah. Penulisan sejarah bersifat sangat terbuka sesuai dengan penemuan-penemuan bukti baru, interpretasi baru, dan tentu saja juga kepentingan-kepentingan baru. Tidak ada yang kekal dalam penulisan sejarah kecuali penulisan kembali sejarah itu sendiri Peran guru sejarah dalam melakukan pencerahan sosial melalui pengajaran sejarah di sekolah tidak perlu disangsikan lagi. Para penyusun kurikulum dan bahan ajar ini lah yang banyak mewarnai paradigma pengajaran sejarah di sekolah. Pengajaran sejarah yang memiliki nilai pencerahan sosial merupakan pengajaran sejarah yang sejauh mungkin menghindari narasi yang banyak memuat pola-pola oposisi biner hitam putih.
\end{abstract}

Kata kunci: Sejarah, Pencerahan

\section{Pendahuluan}

Beberapa bulan yang lalu kontro-versi mengenai pengajaran sejarah di sekolah mencuat kembali. Hal ini bersumber dari kebijakan Mendiknas (Menteri Pendidikan Nasional) Bambang Sudibyo yang melarang penggunaan standar kompetensi mata pelajaran sejarah yang mengacu pada Kurikulum 2004 dan penggunaan buku teks pelajaran sejarah di sekolah/madrasah yang mengacu pada standar kompetensi tersebut untuk tingkat SMP/Madrasah Tsanawiyah dan SMA/Madrasah Aliyah/SM Kejuruan. Larangan itu dikeluarkannya pada rapat kerja dengan Komisi X DPR RI di Jakarta pada tanggal 27 Juni 2005. Menurut Mendiknas, kebijakan itu didasari atas berkembangnya wacana publik yang menilai standar kompetensi mata pelajaran sejarah dalam Kurikulum 2004 tidak sepenuhnya mencatat fakta perjalanan bangsa Indonesia. la mengatakan bahwa peristiwa pemberontakan PKI Madiun 1948 tidak dimuat, peristiwa pemberontakan 1965 hanya memasukkan keterliba-

* Singgih Tri Sulistiyono Guru Besar Sejarah Fakultas Ilmu Budaya Universitas Diponegoro Semarang. 
tan G30S tanpa menyebut keterlibatan $\mathrm{PKI}$, sedangkan pemberontakan seperti PRRI, DI/TII dan Permesta secara eksplisit dimuat. Pemerintah meminta Badan Standar Nasional Pendidikan untuk menyempurnakan dan merumuskan kembali standar komptensi pelajaran sejarah terutama yang terkait dengan keterlibatan PKI dalam pemberontakan terhadap negara ${ }^{1}$

Kebijakan Mendiknas tersebut menimbulkan berbagai pro dan kontra dalam masyarakat. Di satu sisi ada sebagian masyarakat yang mengingin-kan agar tetap mencantumkan kata 'PKl' dalam penyebutan $\mathrm{G} 30 \mathrm{~S}$ (sehingga menjadi $\mathrm{G}$ $30 \mathrm{~S} / \mathrm{PKI})$ dan sebagian masyarakat menghendaki agar kata PKI dihapuskan (sehingga hanya 'G 30 S' saja). Bahkan kontroversi ini juga diwarnai dengan aksi unjuk rasa. Di Surabaya (di depan patung Gubernur Suryo) misalnya, peringatan Hari Pendidikan Nasional diwarnai dengan demo yang dilakukan oleh Forum Merah Putih, yang memperotes penghapusan peran PKI pada peristiwa 1965 dalam kurikulum penidikan sejarah 2004. Mereka mempertontonkan poster dengan tulisan "Awas Sejarah Bohong". Koordinator unjuk rasa Zainal Asyiq mengatakan bahwa muatan kurikulum 2004 pendidikan sejarah berpontesni bagi PKI melakukan pencucian diri dari noda hitam sejarah bangsa dengan memutar balikkan fakta dan membelokkan arah sejarah bangsa pada peristiwa 1965. Sehingga TNI dan umat Islam menjadi pihak yang bertanggungjawab terhadap peristiwa tersebut. ${ }^{2}$ peran PKI pada peristiwa 1965 dalam kurikulum penidikan sejarah 2004. Mereka mempertontonkan poster dengan tulisan "Awas Sejarah Bohong". Koordinator unjuk rasa Zainal Asyiq mengatakan bahwa muatan kurikulum 2004 pendidikan sejarah berpontesni bagi PKI melakukan pencucian diri dari noda hitam sejarah bangsa dengan memutar balikkan fakta dan membelokkan arah sejarah bangsa pada peristiwa 1965. Sehingga TNI dan umat Islam menjadi pihak yang bertanggung-jawab terhadap peristiwa tersebut. ${ }^{3}$

Sementara itu kelompok masyarakat yang menginginkan agar kta $\mathrm{PKI}$ di hapuskan dari frasa G $30 \mathrm{~S} / \mathrm{PKI}$ beralasan bahwa peristiwa tersebut masih belum diteliti secara tuntas. Bahkan bermunculan berbagai teori dari para sejarawan baik asing maupun dalam negeri yang seringkali berbeda pendapat sangat tajam. Paling tidak ada lima versi pendapat mengenai dalang tragedi G $30 \mathrm{~S}$, yaitu: 1)PKI, 2) Klik Ang katan darat, 3) CIA, 4) Presiden Sukarno, 5) Tidak ada pelaku tunggal. ${ }^{4}$ Di samping itu pihak-pihak yang menjadi korban setelah aksi pembersihan terhadap para anggota dan simpatisan ataupun orang yang dianggap anggota dan simpatisan PKI juga tidak sependapat mengenai penggunaan istilah G $30 \mathrm{~S} / \mathrm{PKl}$. Pemberian stigma PKI pada peristiwa $G$ $30 \mathrm{~S}$ dipandang sebagai pembohongan dan penghitaman sejarah. ${ }^{5}$ Oleh karena itu seorang sejarawan dari LIPI menuntut agar diadakan 'pelurusan sejarah' ${ }^{6}$

1 Lihat misalnya 'Buku Sejarah Kurikulum 2004 Dilarang', http://www.suaramerdeka. com/cybernews/harian/0506/27/ nas15.htm. Dikunjungi tanggal 16 Maret 2006.

2 Lihat 'Demo Penghapusan Sejarah PKI Warnai Hardiknas di Grahadi', www.mediaindo.co.id/berita.asp?id=64033. Dikunjungi tanggal 16 Mart 2006 
Adanya berbagai kontroversi dalam penulisan sejarah tersebut di atas menyebabkan dunia pengajaran sejarah di sekolah menghadapi dilema antara mengajar dengan materi 'apa adanya' dan materi yang sudah dimuati dengan pesanpesan moral dan bahkan pesan politis tertentu. Dengan demikian sebagian guru mengalami kebingungan dalam menyampaikan materi pelajaran sejarah terutama yang berhubungan dengan peristiwa Madiun 1948 dan Tagedi tahun 1965. ${ }^{7}$ Dengan demikian ada berbagai perbedaan paradigma dalam pengajaran sejarah di sekolah. Oleh karena itu makalah ini akan mencoba untuk mengkaji paradigma pengajaran sejarah di sekolah dalam kaitannya dengan hakekat sejarah sebagai media untuk pencerahan sosial (history as social enlightenment). Pengajaran sejarah dengan paradigma yang sesui dengan hakekat sejarah akan membebaskan masyarakat dari belenggu mitos masa lampau.

\section{Sejarah dan Persoalan Kekinian}

Jika dibandingkan dengan bidang pengajaran sejarah, penelititan dan penulisan sejarah telah menunjukkan perkembangan yang luar biasa dalam era reformasi ini, terutama dalam kaitannya dengan kebebasan yang diperoleh oleh sejarawan dan para penulis sejarah untuk berkarya. Barangkali hal ini merupakan alah satu pertanda berkembangnya kesadaran sejarah di kalangan masyarakat untuk memahami persoalan kekinian dalam rangka untuk meraih masa depan yang lebih baik. Istilah 'sejarah' dan 'kekinian' memang mengesankan dua kata yang bertolak belakang. Di satu pihak, sejarah berhubungan dengan realitas dan peristiwa masa lalu yang telah hilang, di pihak lain, persoalan 'kekinian' jelas mengacu kepada realitas yang sedang dan akan dihadapi oleh sebuah komunitas. Oleh karena itu pertanyaan yang muncul adalah: apa relevansi dan fungsi penulisan sejarah terhadap persoalan kekinian? Atau lebih ekstrim lagi: apakah penulisan sejarah itu ada gunanya untuk menyelesaikan persoalan kekinian? Pertanyaan itu sering dilontarkan oleh orang yang kurang memiliki kesadaran sejarah sebagai manifestasi dari penilaian sinis terhadap sumbangan sejarah dalam kehidupan sekarang dan masa yang akan datang.

Penulisan sejarah dan kesadaran sejarah memang memiliki kaitan yang sangat erat. Penulisan sejarah akan menjadi salah satu sarana untuk menciptakan kesadaran sejarah. Sebaliknya kesadaran sejarah juga akan menstimulasi penulisan sejarah. Dalam tataran kebangsaan, jika negara bangsa masih dianggap penting, kesadaran sejarah bisa juga merupakan suatu hal yang subyektif dalam arti berkaitan dengan pengalaman dan penghayatan warga bangsa terhadap masa lampaunya. Kesadaran sejarah yang dan penghayatan

3 Lihat 'Demo Penghapusan Sejarah PKI Warnai Hardiknas di Grahadi', www.mediaindo.co.id/berita.asp?id=64033. Dikunjungi tanggal 16 Mart 2006

${ }^{4}$ Lihat Tim ISAl, Bayang-bayang PKI (Jakarta: Institut Studi Arus Informasi, 1995), hlm. 37-38. Lihat juga Asvi Warman Adam, 'Kontrol Sejarah Semasa Pemerintahan Suharto', makalah disampaiakn pada Seminar PraKipnas: Memandang Tragedi Nasional 1965 Secara Jernih (Serpong: 8 September 1999), hlm. 6-9.

${ }^{5}$ Lihat Imam Soedjono, Yang Berlawan: Membongkar Tabir Pemalsuan Sejarah PKI (Yogyakarta: Resist Book, 2006), hlm. v.

${ }^{6}$ Asvi Warman Adam, Pelurusan Sejarah Indonesia (Yogyakarta: TriDE, 2004)

7 'Kurikulum Sejarah Tahun 1994 Membingungkan Guru', Suara Pembaruan, 30 Juni 2005 
warga bangsa terhadap masa lampaunya. Kesadaran sejarah yang ditunjang oleh pengetahuan masa lampau yang 'obyektif' akan menimbulkan empati warga bangsa terhadap bangsanya dengan cara 'relive' dan 'rethink' terhadap tindakan-tindakan pendahulunya pada masa lampau. ${ }^{8}$ Untuk selanjutnya, empati ini akan membangkitan keingintahuan mereka untuk menggali lebih dalam perjalanan bangsanya di masa lampau dalam rangka untuk menemukan jawaban dari pertanyaan mengapa segala sesuatu menjadi seperti apa yang terlihat pada masa kini. Warga bangsa yang memiliki kesadaran sejarah akan mencari jawabannya bukan hanya dengan belajar sejarah tetapi juga belajar dari sejarah, sebagai-mana yang pernah didengungkan oleh Bung Karno. Mungkin setelah itu mereka akan menjadi lebih arif dan bisa mem-berikan sumbangan pemikiran ke arah mana seharusnya perjalanan bangsa ini mesti ditempuh, sebab kesadaran sejarah merupakan salah satu bentuk empati intelektual.

Seorang filsof idealis Itali abad XX, Benedetto Croce (1866-1952), yang telah menempatkan perspektif kekinian dalam penulisan sejarah, mencemoohkan usaha untuk mencapai obyektivitas masa lampau as it actually happened sebagaimana yang pernah dianjurkan oleh sejarawan empiris Leopold von Ranke (1795-1886). ${ }^{9}$ Croce menganjurkan untuk tidak mempedulikan interes kekinian yang tidak dapat dihindarkan oleh sejarawan. Sesungguhnya menceritakan 'apa adanya' (jajaran fakta) tentang peristiwa masa lampau bukanlah sejarah, tetapi semata-mata bangkai dari sejarah, sedangkan sejarah yang sesungguhnya adalah an act of spirit. Oleh karena itu ia menulis: 'every true history is contemporary history' dan konsekuensinya adalah bahwa setiap generasi akan menulis sejarahnya sendiri sesuai dengan kepentingan-kepentingan mereka sendiri di masa dalam dimensi kekinian. 10 Sementara itu kronik telah mati dalam pikiran, yaitu berarti tidak hidup dalam pikiran atau pengalaman sejarawan padahal dalam pemahaman terhadap masa lampau itu sejarawan mengenangkan kembali peristiwa-peristiwa masa lampau itu di dalam pikirannya kemudian dituangkan dalam bentuk tulisan.

Dengan dasar itu, penulisan sejarah bersifat sangat terbuka sesuai dengan penemuan-penemuan bukti baru, interpretasi baru, dan tentu saja juga kepentingan-kepentingan baru. Oleh sebab itu perlu ada desakralisasi dalam penulisan sejarah. Artinya hasil penulisan sejarah (historiografi) perlu ditinjau kembali sejalan dengan perubahan- perubahan yang terjadi di dalam masyarakat. Tidak ada yang sempurna mampu untuk untuk menampilkan realitas masa lampau yang utuh sebagaimana adanya. Selalu saja ada keterbatasan kemampuan dan sumber sejarah. Realitas yang obyektif hanya ada sejauh menyangkut sejarah sebagai sebuah peristiwa masa lampau yang tidak akan terulang. Sementara itu sejarah sebagai hasil rekonstruksi sejarawan merupakan produk dari bahasa, wacana, dan pengalaman sejarawan

8 H. Stuart. Hughes, History as Art and as Science (New York: 1964), hlm. 1-21.

9 Raymond Aron, 'Relativism in History', dalam: Hans Meyerhoff, The Philosophy of History in Our Time: An Anthology (New York: Anchor Original Publisher, 1959), hlm. 153..

B. Croce, 'History and Cronicle', dalam: Meyerhoff, The Philosophy, hlm. 44. 
dalam konteks sosial dan kultural tertentu. ${ }^{11} \mathrm{Apa}$ yang disebut sebagai fakta sejarah itu sendiri sebetulnya ada di dalam pikiran sejarawan (yang diperoleh melalui ingatan atau melalui bukti tidak langsung dari jejak-jejak kelampauan, laporan lisan, dan dokumen tertulis) yang kemudian dideskripsikan dalam bentuk tulisan. Hal ini sesuai dengan yang dikemukakan oleh Croce dan Collingwood bahwa sesungguhnya sejarawan lah yang memainkan peranan aktif dalam mengonstruksi sejarah (sebagai narasi) dengan melakukan 'rethinking' terhadap realitas masa lampau. ${ }^{12}$

'Kontaminasi kekinian' terhadap penulisan sejarah juga dikemukakan oleh Lovejoy yang mengatakan bahwa sejak awal pemilihan tema atau topik penelitian sejarah, sejarawan sudah menggunakan prinsip-prinsip tertentu sesuai dengan kepentingannya. Menurutnya historiografi, lebih dari sekedar kronik, bukan hanya bersifat selektif tetapi juga interpretatif dan eksplanatif. Dengan demikian meskipun historiografi berisi tentang masa lampau tetapi sesungguhnya merupakan gejala kekinian yang ditentukan oleh motif-motif yang ada di dalam pikiran sejarawan yang mewakili jamannya. Dalam konteks ini mestinya sejarah bukan hanya berfungsi sebagai nostalgia saja yang bersifat rekreatif dan tidak hanya sebagai alat pembenar saja dari kekuasaan yang represif tetapi lebih dari itu bisa menjadi wahana pencerah bagi masyarakat dari kungkungan tirani mitos-mitos kelampauan. Tulisan sejarah mestinya bisa mencairkan kebekuan-kebekuan dalam hubungan-hubungan sosial yang menye- babkan konflik-konflik berkepanjangan dalam masyarakat. Artinya, untuk kepentingan Indonesia saat ini (itupun jika kita masih memiliki komitmen untuk mempertahankan Indonesia sebagai sebuah negara bangsa), historiografi mestinya bisa menjadi wahana untuk rujuk sosial yang saat ini sangat diperlukan oleh masyarakat Indonesia.

\section{Pengajaran Sejarah sebagai Pencerahan Sosial}

Beberapa bulan yang lalu, Presiden SBY (Susilo Bambang Yudhoyono) mengajak GAM (Gerakan Aceh Merdeka) melupakan peristiwa-peristiwa buruk di masa lalu dan menatap ke masa depan untuk mewujudkan suasana damai pasca ditandatanganinya nota kesepakatan di Helsinki (Finlandia). ${ }^{13}$ Apa yang menarik dari ajakan SBY itu adalah bahwa hanya dengan melupakan sejarah (masa lampau) yang pahit, sebuah harmoni sosial masa kini dan mendatang dapat dicapai. Ajakan itu juga mengisyaratkan bahwa dengan menguak kisah sejarah justru akan menjadi handicap bagi terwujudnya sebuah rujuk sosial (social reconciliation) ataupun harmoni sosial (social harmony) ketika masyarakat memiliki memori kolektif yang penuh dengan konflik dan kekerasan. Dalam konteks itu perlu diajukan pertanyaan apakah melupakan masa lampau merupakan jalan untuk sebuah rujuk sosial ketika masyarakat sedang menghadapi persoalan konflik social? Apakah betul bahwa masa lampau yang penuh dengan konflik dan kekerasan yang sangat menyakitkan tidak layak

\footnotetext{
${ }^{11}$ Bambang Purwanto \& Asvi Warman Adam, Menggugat Historiografi Indonesia (Yogyakarta: Ombak, 2005), hlm. 46 .

${ }^{12}$ Alun Munslow, Deconstructing History (Routledge, 1997), hIm. 20.

13 'SBY ajak GAM Lupakan Masa Lalu', Suara Merdeka (16 Agustus 2005).
} 
untuk dikenang atau harus dilupakan? Barangkali memang betul bahwa melupakan masa lampau atau bahkan mengubur/ membunuh masa lampau (killing the past) merupakan salah satu cara untuk memcapai rujuk sosial. Akan tetapi persoalannya adalah apakah hal itu bisa dilakukan secara massal?

Bagi masyarakat Indonesia saat ini yang mulai hidup dalam era reformasi dan keterbukaan yang diwarnai dengan berbagai konflik yang berkepanjangan baik yang mengarah pada disintegrasi sosial maupun disintegrasi nasional, pemberdayaan sejarah untuk ikut ambil bagian aktif dalam proses pencerahan social perlu mendapatkan perhatian yang serius. Wacana ini sekaligus merupakan upaya kecil untuk merespon sinyalemen bahwa pada saat ini para sejarawan akademis mengalami disorientasi historio -grafis sehingga tulisan-tulisan mereka tidak memiliki akar persoalan dari masyarakatnya atau mereka berdiri di atas menara gading, sehingga karya-karya mereka dipandang tidak mampu mencerahkan masyarakat dan tidak memiliki sumbangan apa-apa terhadap pemecahan persoalan kekinian apalagi untuk masa yang akan dating. ${ }^{14}$ Padahal seharusnya tugas dari narasi sejarah adalah untuk memahami masa kini. Dalam hal ini sesungguhnya peran pengajaran sejarah di sekolah menjadi sangat penting dalam proses pencerahan social ini, karena lewat pengajaran sejarah para generasi muda menerima eksplanasi historis dari berbagai persoalan yang kini dihadapi oleh masyarakat. Dengan demikian generasi muda tidak akan terkungkung oleh ketidak- tahuannnya atau kesalahpengetahuannya mengenai masa lampau sehingga akan keliru juga dalam bertindak pada masa kini dan di masa depan. Jika hal ini terjadi berarti masa depan Indonesia dibangun di atas puing-puing sejarah yang menyesatkan.

Sudah barang tentu corak materi pengajaran sejarah yang digunakan di sekolah-sekolah tergantung pada kurikulum dan bahan ajarnya. Sementara itu kurikulum dan bahan ajar bergantung kepada para penyusunnya. Jadi para penyusun kurikulum dan bahan ajar ini lah yang banyak mewarnai paradigma pengajaran sejarah di sekolah. Dalam konteks ini, secara garis besar ada dua paradigma dalam pengajaran sejarah yaitu yang bersifat selektif dan bersifat apa adanya. Paradigma yang bersifat selektif cenderung memiliki prinsip untuk memberikan materi pembelajaran sejarah hanya setelah melalui proses seleksi dengan menggunakan pertimbangan moral dan kepentingan tertentu. Artinya tidak semua peristiwa sejarah boleh diajarkan kepada para siswa. Oleh karena sudah melalui seleksi dengan dasar pertimbangan moral dan kepentingan tertentu, materi pembelajaran sejarah juga cenderung untuk bersifat menghukumi hitam-putih, baik-buruk, dan bahkan benar dan salah yang bersifat deterministik. Pembelajaran sejarah hampir tidak ada bedanya dengan sebuah pengadilan yang melahirkan siapa pemenang (the winner) dan siapa pecundang(the loser). Hal ini melahirkan kesan yang cukup mendalam bahwa sejarah adalah kisah sang pemenang dan dalam kisah seperti itu

\footnotetext{
${ }^{14}$ Bambang,Purwanto, 'Sejarawan Akademik dan Disorientasi Historiografi: Sebuah Otokritik', Pidato Pengukuhan Jabatan Guru Besar pada Fakultas IImu Budaya Universitas Gadjah Mada (Ygyakarta: 28 September 2004), hlm. 6-12.
} 
sang pecundang tidak mendapat-kan tempat yang layak. Padahal sang pemenang menjadi pemenang karena ada sang pecundang yang kalah. Oleh karena itu secara sinis bisa dikatakan bahwa mestinya pemerintah Orde Baru pada waktu itu harus berterima kasih kepada PKI (Partai Komunis Inodnesia), sebab dengan adanya PKI yang dikalahkan (atau ada orang yang sering mengatakan 'dikorbankan') itulah pemerintah Orde Baru dapat memegang tampuk pemerintahan selama lebih dari tiga dekade. Hal itu menyiratkan arti bahwa sejarah sang pecundang juga mempunyai hak untuk ditempatkan secara proporsional dalam kisah sejarah sebagai memori kolektif. Dalam konteks inilah monopoli terhadap kebenaran sejarah oleh sang pemenang harus dihilangkan sebab akan melahirkan kisah sejarah yang penuh dendam dan fatalistik yang melihat persoalan secara hitam putih yang justru akan melanggengkan konflik sosial yang ada di dalam masyarakat. Paradigma monopolistik semacam ini biasanya diterapkan oleh para pemenang yang menginginkan status quo yang langgeng. Namun demikian cara berpikir yang seperti ini sering juga dianut oleh para pecundang yang menginginkan sebaliknya. Mereka ingin membongkar bahwa narasi sejarah versi sang pemenang dianggap kebohongan semata. Jadi cara berpikir mereka sama yang kepentingannya yang berbeda.

Seringkali juga muncul wacana bahwa konflik sosial yang sedang dihadapi oleh masyarakat dapat dikurangi dengan cara mengubur masa lampau. Ajakan semacam ini biasanya datang dari sang pemenang yang telah menjadi penguasa yang menginginkan kekuasaannya stabil atau sudah merasa aman, namun apakah sang pecundang yang menjadi korban dapat melupakan kepahitan masa lampau yang penuh dengan dendam yang membara?
Andaipun sang korban bisa menerima masa lampau sebagai sebuah keniscayaan yang sudah ginaris oleh suratan takdir, apakah generasi setelah mereka juga bisa menerima hal yang sama? Apa yang seringkali terjadi justru sebaliknya. Para korban itu menuntut adanya pengungkapan yang obyektif masa lampau. Ada juga yang menuntut adanya 'pelurusan sejarah' atau bahkan semacam pengadilan sejarah.

Dengan demikian ada dua kutub yang berbeda dalam kaitannya dengan pertanyaan apakah penulisan sejarah dapat diperankan sebagai sarana rujuk sosial dalam sebuah masyarakat konflik. Kutub pertama berpendapat bahwa untuk mencapai sebuah rujuk sosial, semua elemen dalam masyarakat harus mengubur dalamdalam masa lampau yang penuh dengan konflik dan kekerasan atau mengekspose fenonema historis tertentu (secara selektif) untuk kepentingan pelanggengan kekuaaan. Kutub ke dua justru berpendapat sebaliknya yaitu bahwa untuk mencapai rujuk sosial perlu pengungkapan masa lampau sejelasjelasnya dalam rangka untuk mencari keadilan dalam sejarah (mungkin karena mereka tidak bisa menemukan keadilan di pengadilan). Namun demikian sayang sekali bahwa kedua kutub tersebut sama-sama sulit untuk dilakukan, apalagi jika jarak antara peristiwa dan penulisan sejarah itu masih demikian dekat. Sikap mereka yang 'ikhlas' untuk mengubur masa lalu biasanya tidak bisa diterima oleh pihak yang 'merasa dirugikan' dalam 'penghilangan sejarah'. Demikian juga sikap mereka yang yang ingin mencapai rujuk social dengan cara membuat 'pengadilan sejarah' juga sulit diterima banyak orang justru karena subyektivitas dalam penulisan sejarah itu sendiri, apalagi jika pihak yang akan diadili itu masih memegang tampuk kekuasaan. Jika kelompokkelompok sosial yang berkonflik tersebut masih berpikir secara hitam putih maka 
persoalan itu tidak akan dapat diselesaikan dengan baik.

\section{Peran Guru}

Peran guru sejarah dalam melakukan pencerahan sosial melalui pengajaran sejarah di sekolah tidak perlu disangsikan lagi. Guru menjadi ujung tombak yang semestinya mampu menjelaskan fenomena kekinian dari perspktif historis. Dengan demikian pengajaran sejarahpun juga harus bersifat kontekstual dan berbasis pada permasalahan (problem-based learning). Seperti dketahui bahwa hingga saat ini pembelajaran sejarah di sekolah masih sering terbelenggu oleh penguasaan cerita masalampau tanpa dikaitkan dengan kehidupan masyarakat sekarang. Oleh sebab itu tantangan utama guru sejarah adalah bagaimana menghubungkan masa lampu dengan kepentingan sekarang agar pembelajaran sejarah juga mempunyai fungsi yang signifikan dalam kehidupan masyarakat sekarang.

Namun demikian persoalannya adalah bagaimana guru sejarah mampu memberikan pencerahan sosial kepada murid-muridnya melalui pengajaran sejarah. barangkali ada beberapa ciri pengajaran sejarah yang mampu mmberikan pencerhan social kepda masyarakat. Pertama, pengajaran sejarah seharusnya mampu memberikan sumbangan dalam proses pembentukan masyarakat madani yaitu masyarakat yang demokratis, memiliki trust, menerima pluralisme, tidak mengharamkan perbedaan, dan sebagainya (Purwanto, 2005: 50). Jadi sebaliknya jika pengajaran sejarah akan menghasilkan generasi yang anti demokrasi, mengalami sindrom krisis kepercayaan, tidak toleran dan mengharamkan keragaman, maka pengajaran sejarah telah gagal mengemban fungsinya sebagai pencerah masyarakat.
Untuk itu para guru sejarah perlu memiliki sikap yang demokratis, menghargai pendapat siswa, dan mau menerima perbedaan. Di samping itu para guru sejarah seyogyanya mampu menjelaskan perbedaan antara sejarah dan indoktrinasi. Barangkali guru perlu menjelaskan kepada siswa mengenai hakekat ilmu sejarah yang selalu dinamis, berkembang dan terbuka. Siapapun memiliki kebebasan untuk menulis apapun sejauh bisa dipretanggungjawabkan secara rasional. Dalam hal ini masyarakat harus diberi pencerahan untuk dapat menerima perbedaan pendapat dan hasil penelitian mengenai sejarah. Demikian juga masyarakat harus diberi 'otonomi' untuk menilai karya-karya historiografis yang ada di hadapan mereka. Hal ini berkaitan dengan kenyataan bahwa pemahaman tentang berbagai perbedaan dan konflik yang ada lebih diperkuat oleh pandangan yang berlawanan daripada oleh upaya untuk mengartikulasikan konsensus. Dengan demikian, menurut Burke, harus ada prubahan dari 'voice of history' menuju kepada 'varied and opposing voices' atau dari monoglossia menuju ke heteroglossia (Burke, 1991: 6). Biarlah masyarakat terbiasa dengan perbedaan pendapat dan menilai sendiri setiap karya sejarah. Emansipasi penulisan sejarah akan melunturkan mitos-mitos yang muncul dari karyakarya sejarah itu sendiri. Dengan demikian kebijakan menutupnutupi peristiwa sejarah tertentu untuk tidak disampaikan kepada siswa perlu ditinjau kembali. Pelajaran dari sejarah sebetulnya bukan hanya berasal dari peristiwa yang dianggap sebagai sebuah kemenangan dan mem-banggakan tetapi juga dari peristiwa kekalahan yang dianggap memalukan. Semua peritiwa baik kemenangan atau kekalahan, kejayaan atau kemunduran, membanggakan atau melalukan akan memberikan hikmah yang sama. 
Kedua, pengajaran sejarah yang mampu mencerahkan masyarakat adalah pengajaran yang 'manusiawi', artinya betapapun hebatnya seseorang yang dianggap tokoh sejarah atau sebaliknya betapapun kerdilnya jiwa seseorang yang dilecehkan dalam sejarah, tentu memiliki kelebihan dan kekurangabn masing-masing. Sejarah yang dinarasikan oleh guru adalah sejarah manusia, bukan sejarah para malaikat yang kalis dengan salah dan kilaf. Oleh karena itu pengajaran sejarah yang memiliki nilai pencerahan social adalah pengajaran sejarah yang sejauh mungkin menghindari narasi yang banyak memuat pola-pola oposisi biner hitam puth antara pemenang dan pecundang atau antara pahlawan dan pengkianat, sebab stigma-stigma semacam itu bersifat situasional dan subyektif. dan akan menyebabkan proses pelanggengan prasangka, dendam dan desintegrasi sosial.

\section{Penutup}

Reformasi yang bergulir sejak tahun 1998 ternyata tidak hanya semata-mata bermakna sebagai tumbangnya pemerintahan Orde Baru yang berkuasa selama lebih dari 30 tahun. Makna yang justru lebih penting adalah adanya perubahanperubahan yang mengikuti reformasi itu sendiri yang mencakup hampir semua bidang kehidupan bangsa Indonesia baik dalam bidang politik, pers, sosial, maupun dalam bidang pemerintahan.

Perubahan yang juga sangat menyolok adalah munculnya iklim kebebasan dalam penulisan sejarah (historiografi) yang selama pemerintahan Orde Baru banyak mendapatkan perlakuan yang represif kecuali jenis sjarah yang 'direstui' oleh pemerintah. Namun demikian sayang sekali bahwa perkembangan yang luar biasa dalam penulisan sejarah ini belum diiringi dengan perubahan paradigma dalam pengajaran sejarah. Bahkan setelah reformasi berlangsung selama 7 tahun terjadi langkah mundur dalam pengajaran sejarah dengan pembekuan kurikulum 2004 untuk mata pelajaran sejarah dan kembali kepada kurikulum 1994 yang merupakan produk pemerintahan Orde Baru yang selama reformasi menjadi bahan cercaan sebagai biang keladi krisis multidimensional yang belum terpecahkan hingga aat ini. Fenomena semacam ini akan menambah kebingungan para pengajar sejarah di sekolah.

Pada tahun-tahun pertama reformasi, kebingungan pengajar sejarah bersumber dari perkembangan yang tidak terbendung dari penulisan sejarah (baik di media massa maupun lewat berbagai penerbitan buku) yang sangat bebas. Semua persoalan yang tabu pada masa Orde Baru dibongkar terutama yang berkaitan dengan mantan Presiden Suharto dan berbagai persoalan yang berhubungan dengan PKI. Sementara itu para pengajar sejarah masih menggunakan kurikulum lama (1994), sehingga perkembangan penulisan sejarah di luar institusi sekolah relatif tidak terakomodasi, kecuali jika pengjar sejarah itu kreatif mengikuti perkembangan historiografi selama periode reformasi.

Kini ketika para pengajar sejarah mulai dapat melakukan akomodasi terhadap perkembangan historiografi di dalam masyarakat, kurikulum sejarah harus berganti lagi. Dengan demikian para pengajar sejarah seyogyanya mengambil langkah-langkah penting untuk menunaikan tugasnya mengajarkan sejarah yang dapat berfungsi sebagai pencerah masyarakat, yaitu bahwa pengajaran sejarah seharusnya mampu menciptakan masyarakat madani yang demokratis, terbuka, toleran, menghalalkan perbedaan, dan sebagainya. Untuk itu guru harus mampu beraktualisasi diri sebagai insan yang demokratis, jujur, toleran, menghargai 
perbedaan pendapat, dan sebagainya. Selain itu, apapun kurikulumnya, jika pengajar sejarah masih menginginkan pengajarannya dapt menjadi waana penceraan sosial maka pengajar sejarah semestinya mampu menyajikan narasi sejarah yang tidak deterministik yang melihat peristiwa sejarah secara hitam-putih yang akan melanggengkan dendam sosial di dalam masyarakat. Dengan cara demikian sejarah akan berfungsi sebagai pencerah sosial dan sekaligus sebagai pembebas cara berpikir masyarakat yang terkungkung dengan mitos dan berhala-berala masa lampau. 